\title{
Effect of cadmium on gametogenesis and offspring of the sea urchin Strongylocentrotus intermedius
}

\author{
N. K. Khristoforova ${ }^{1}$, S. M. Gnezdilova ${ }^{2}$ and G. A. Vlasova ${ }^{1}$ \\ 1 Laboratory of Geochemistry, Pacific Institute of Geography and \\ 2 Laboratory of Gametogenesis, Institute of Marine Biology, Far East Science Center, Academy of Sciences of the USSR, \\ Vladivostok 690022, USSR
}

\begin{abstract}
Effects are examined of chronic exposure to cadmium sulfate(5, 1, 0.5 and $0.1 \mathrm{mg} \mathrm{Cd} \mathrm{l}^{-1}$ ) on gametogenesis of mature sea urchins Strongylocentrotus intermedius, and on the development of their offspring. Embryogenesis in uncontaminated sea water ( $33 \%$ S) was observed up to the early pluteus. At $5 \mathrm{mg} \mathrm{Cd} \mathrm{l^{-1 }}$, test animals died within several $h_{\text {; }}$ at $1 \mathrm{mg} \mathrm{Cd} \mathrm{l}^{-1}$ within several $\mathrm{d}_{\text {; }}$ at $0.5 \mathrm{mg}$ $\mathrm{Cd} \mathrm{l}^{-1}$ within $1 \mathrm{mo}$. Cd concentrations of 0.5 and $1 \mathrm{mg} \mathrm{l}^{-1}$ induced obvious anomalies in ovocytes. Long-term exposure of adults to $0.1 \mathrm{mg} \mathrm{Cd}^{-1}$ produced no changes in external appearance nor any obvious histological alterations in gonads; nevertheless, such exposure led to the production of anomalous sex cells and resulted in inviable offspring.
\end{abstract}

\section{INTRODUCTION}

An outburst in Japan of 'itai-itai' disease (Kobayashi, 1971), caused by cadmium contamination of aquatic environments, induced studies on cadmium exchange in the sea. Of the abundant literature on the subject we consider here only some problems. These include cadmium accumulation in marine animals and plants; cadmium effects on organisms during ontogenesis with emphasis on embryogenic and larval stages; combined effects of cadmium, salinity and temperature on growth and survival of molluscs and fishes (a problem particularly important in estuaries); as well as mechanisms of immobilization and detoxication of cadmium, and tolerance to cadmium with special relation to metal-binding proteins, the metallothioneins.

The negative effect of cadmium on generative functions of higher animals has been known for some time (Nozdryukhina, 1977). Pařizek (1977) has shown a specific effect of cadmium salts on the reproductive system in the rat. Parenteral introduction of cadmium chloride caused hemorrhagic necrosis of rat testes and ovaries. Injections of cations of other heavy metals, even mercury, are not followed by similar changes. The mechanisms of $\mathrm{Cd}$ damage to the generative functions of gonads are still unknown.

Among invertebrates, sea urchins are a promising object for studying the effect of toxicants on the reproductive system. In these animals, the entire game- togenesis from ovogonia to ripe egg cells occurs - in contrast to other invertebrates - within the gonad (Gnezdilova et al., 1979). This provides a unique opportunity to follow the damaging effect of $\mathrm{Cd}$ on the various stages of differentiating sex cells. There are still other advantages: a large number of gametes and synchronously developing embryos are available, embryos are easily incubated, and many observations can be carried out on sea urchins in vivo. Hence, the effect of previous chronic exposure to cadmium on gametogenesis of mature individuals can be observed in the quality of the offspring (developing embryos).

This paper reports on the effect of chronic exposure to cadmium on the development of sex cells and embryogenesis in Strongylocentrotus intermedius, a common representative of the fauna in the sublittoral zone of the Sea of Japan.

\section{MATERLALS AND METHODS}

Experiments were conducted in aquaria at 'Vityaz' field station in June-July 1981. Strongylocentrotus intermedius were kept in closed aerated aquaria, and the sea water was changed daily. The sea urchins were fed Laminaria and Ulva. After an adaptation period, cadmium sulfate was added to the aquarium water to obtain final concentrations of $5,1,0.5$ and $0.1 \mathrm{mg}$ $\mathrm{Cd}^{-1}$. The control aquarium was filled with sea water 
from Vityaz Bay (Sea of Japan). According to Patin et al. (1980), natural $\mathrm{Cd}$ concentration in the bay does not

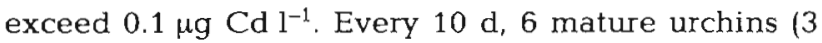
males and 3 females) were selected for embryological experiments and histological diagnosis. The urchins were sexed by the colour of sex products excreted from gonopores on electrical stimulation. To obtain ripe eggs, $0.5 \mathrm{M} \mathrm{KCl}$ was injected into the perivisceral cavity of sampled females. Using standard procedures, egg cells were artificially inseminated in Petri dishes of clean filtered sea water (nembrane filter, $0.45 \mu \mathrm{m}$ mesh). Development of fertilized eggs was noted in terms of 5 developmental stages: formation of fertilization membrane, first cleavage with formation of 2 blastomeres, middle blastula, middle gastrula, and early pluteus. Experiments were conducted at $20{ }^{\circ} \mathrm{C} \pm 0.5 \mathrm{C}^{\circ}$ and $33 \% \mathrm{~S}$; they were repeated in 3 replicates.

For morphological investigation, small pieces of female gonads were fixed in Navashin solution (chromic acid - formalin - glacial acetic acid, 10:4:1), washed in running water, passed through increased grades of alcohol, dehydrated and imbedded in paraffin. Caracci hematoxylin and, additionally, $1 \%$ eosin were used to stain $5 \mu \mathrm{m}$ sections. Sections were examined histologically for qualitative changes in sex cells, and ovogonia in acini were counted. Twenty average-sized acini were used for morphometry.

\section{RESULTS}

As reported earlier (Fuji, 1960a, b; Gnezdilova, 1971; Yakovlev, 1980), acini of sea urchin ovaries contain - along their inner wall - attached ovogonia in their primary, generative stage, and ovocytes, produced during gonial division. By the end of the following vegetative phase of growth, free ovocytes lie in the acinus lumen. By the beginning of the spawning, these ovocytes accomplish vitellogenesis to form ripe gametes (egg cells). In addition to sex cells, ovaries of the sea urchins contain morphologically variable accessory cells, containing eosinophilic and basophilic globules of different sizes. The accessory cells contribute to nutrition of growing gametes and to resorption of unspawned egg cells. We distinguished 5 stages of gonad growth in terms of dominant ovocystes: passivity, beginning of growth, active gametogenesis, prespawning and spawning stages (Gnezdilova, 1971).

Gonads under study were in the stage of active gametogenesis. Acini contained mostly attached and free ovocytes. Egg cells and ovogonia were fewer in number. Fig. 1 to 3 show attached and free growing ovocytes, ripe egg cells and accessory cells.

Effects of chronic exposure of sea urchins to cadmium will be presented separately for each tested concentration.

Cd concentration of $5 \mathrm{mg} \mathrm{F}^{-1}$. All experimental sea urchins died a few hours following addition of $\mathrm{Cd}$. No morphological changes were found in their gonads.

$C d$ concentration of $1 \mathrm{mg} \mathrm{r}^{-1}$. All test urchins were dead $13 \mathrm{~d}$ after $\mathrm{Cd}$ addition. Artificial insemination after $10 \mathrm{~d}$ exposure resulted in very poor fertilization, and early development stopped at the gastrula stage (Table 1).

Microscopic study of fixed ovary material showed resorption of the majority of ovocytes. Both growing ovocytes and ripe cells underwent degenerative altera-

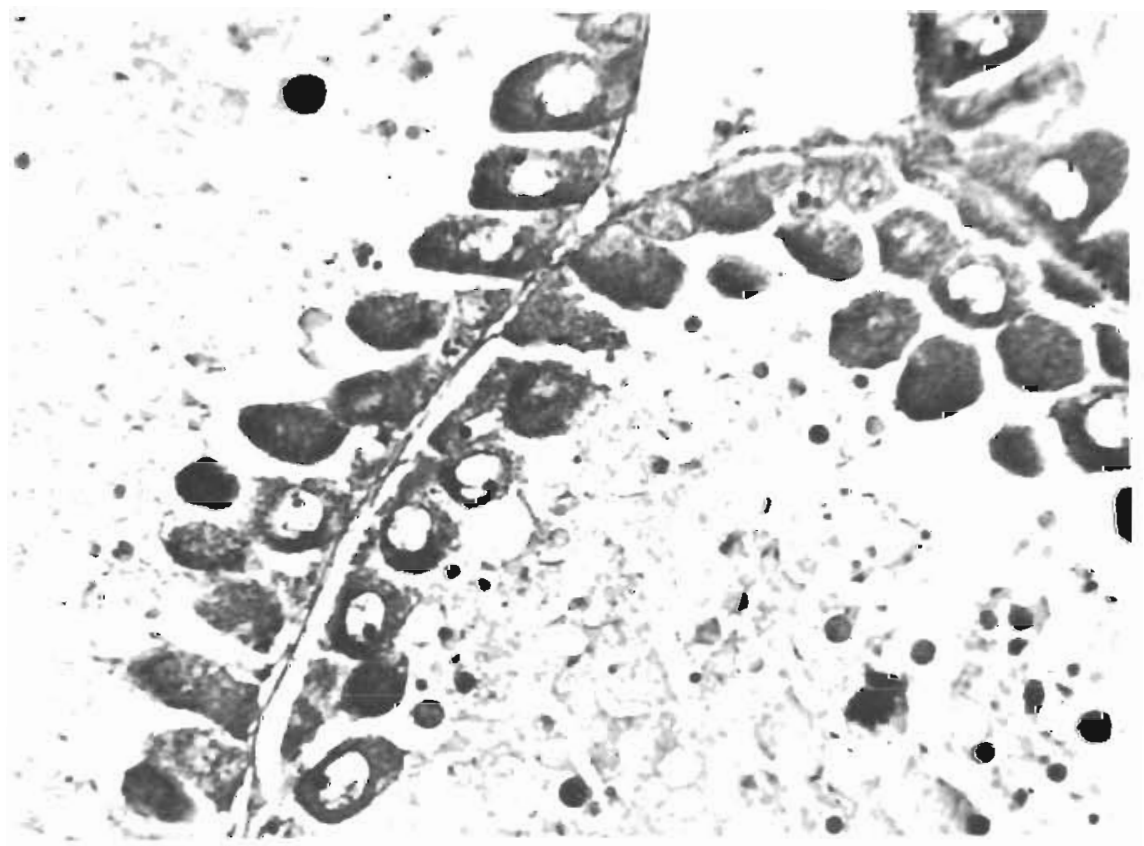

Fig. 1. Strongylocentrotus intermedius. Gonad wall. Growing ovocytes attached to acinus wall; accessory cells in the middle. Stain: hematoxylin Caracci; additional staining with eosin. Magnification $300 \mathrm{X}$ 
Fig. 2. Strongylocentrotus intermedius. Gonad in stage of active gametogenesis. Free ovocytes lying in the acinus lumen. Stain and magnification: as in Fig. 1

Fig. 3. Strongylocentrotus intermedius. Spawning gonad. Acini filled with egg cells. Stain and magnification: as in Fig. 1
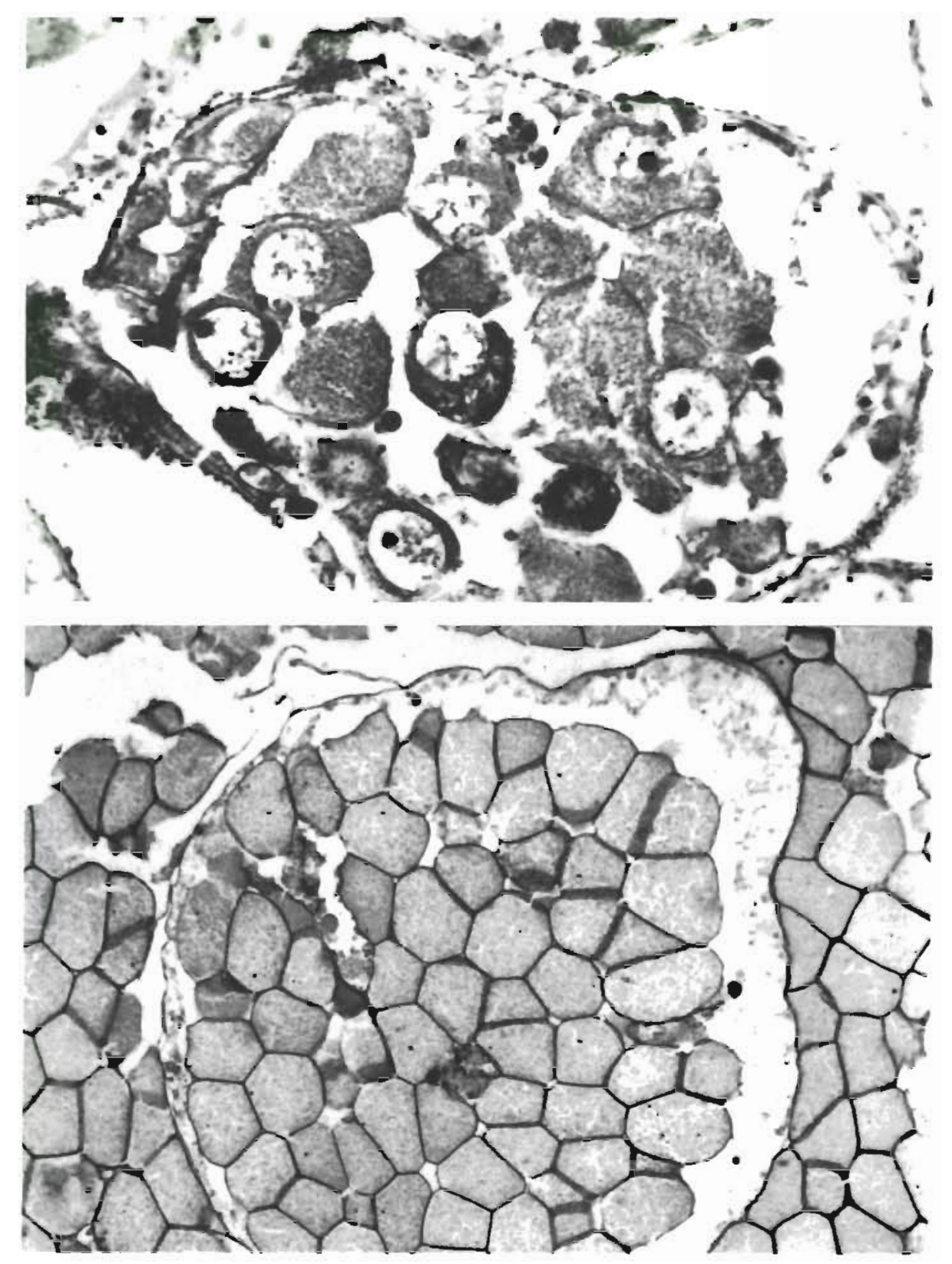

Table 1. Strongylocentrotus intermedius. Embryogenesis after exposure of mature sea urchins to cadmium solution

\begin{tabular}{|c|c|c|c|c|c|c|}
\hline \multirow{2}{*}{$\begin{array}{c}\text { Concentration } \\
\left(\mathrm{mg} \mathrm{Cd} \mathrm{l}^{-1}\right)\end{array}$} & \multirow{2}{*}{$\begin{array}{l}\text { Date of } \\
\text { observ. }\end{array}$} & \multicolumn{5}{|c|}{ Normal embгуоs (\%) for developmental stages } \\
\hline & & $\begin{array}{l}\text { Fertiliz. } \\
\text { membrane }\end{array}$ & $\begin{array}{c}\text { Two } \\
\text { blastomeres }\end{array}$ & Blastula & Gastrula & Pluteus \\
\hline Control & $\begin{array}{r}8.07 \\
26.07\end{array}$ & $\begin{array}{l}96.4 \\
97.3\end{array}$ & $\begin{array}{l}94.2 \\
94.0\end{array}$ & $\begin{array}{l}94.4 \\
94.0\end{array}$ & $\begin{array}{l}93.3 \\
99.5\end{array}$ & $\begin{array}{l}94.5 \\
97.8\end{array}$ \\
\hline 0.1 & $\begin{array}{r}8.07 \\
17.07 \\
4.08\end{array}$ & $\begin{array}{l}48.0 \\
96.2 \\
91.0\end{array}$ & $\begin{array}{l}88.0 \\
88.9 \\
90.5\end{array}$ & $\begin{array}{l}64.8 \\
77.2 \\
76.5\end{array}$ & $\begin{array}{l}84.4 \\
79.5 \\
87.1\end{array}$ & $\begin{array}{l}0.0 \\
0.0 \\
0.0\end{array}$ \\
\hline 0.5 & $\begin{array}{r}8.07 \\
17.07\end{array}$ & $\begin{array}{l}51.1 \\
86.7\end{array}$ & $\begin{array}{l}71.0 \\
90.5\end{array}$ & $\begin{array}{l}81.2 \\
80.5\end{array}$ & $\begin{array}{l}57.4 \\
74.4\end{array}$ & $\begin{array}{l}0.0 \\
0.0\end{array}$ \\
\hline 1.0 & 16.07 & 36.0 & 91.0 & 67.8 & 55.7 & 0.0 \\
\hline
\end{tabular}


tions. Resorption of ovocytes started in the apical part of cells. Cell borders became indistinct, as the cell membranes partly resorbed. Large globules of accessory cells intruded ovocytes, gradually filled and destroyed the entire cytoplasm (Fig. 4). Egg cells resorbed similarly (Fig. 5).

$C d$ concentrations of $0.5 \mathrm{mg} \mathrm{l}^{-1}$. The urchins survived in this concentration for $33 \mathrm{~d}$. As at the $1 \mathrm{mg} \mathrm{l}^{-1}$ concentration, fertilization did not occur by artificial insemination on the tenth day of exposure. A separated fertilization membrane was observed only in half of the egg cells. Embryogenesis ceased at the gastrula stage, which formed $1.5 \mathrm{~h}$ later than in the control. However, by the twentieth day of $\mathrm{Cd}$ exposure, the number of fertilized eggs in the urchins of this aquarium increased sharply to $86.7 \%$. The effect on embryogenesis was the same: it did not proceed beyond the gastrula stage

Histological study showed that exposure of sea urchins to this Cd concentration had 2 effects. First, formation of ovogonia was stimulated: by the end of the twentieth day the number of ovogonia contained in acini of test individuals was 1.5 times greater than in the controls (Fig. 6). Second, and similar to the results

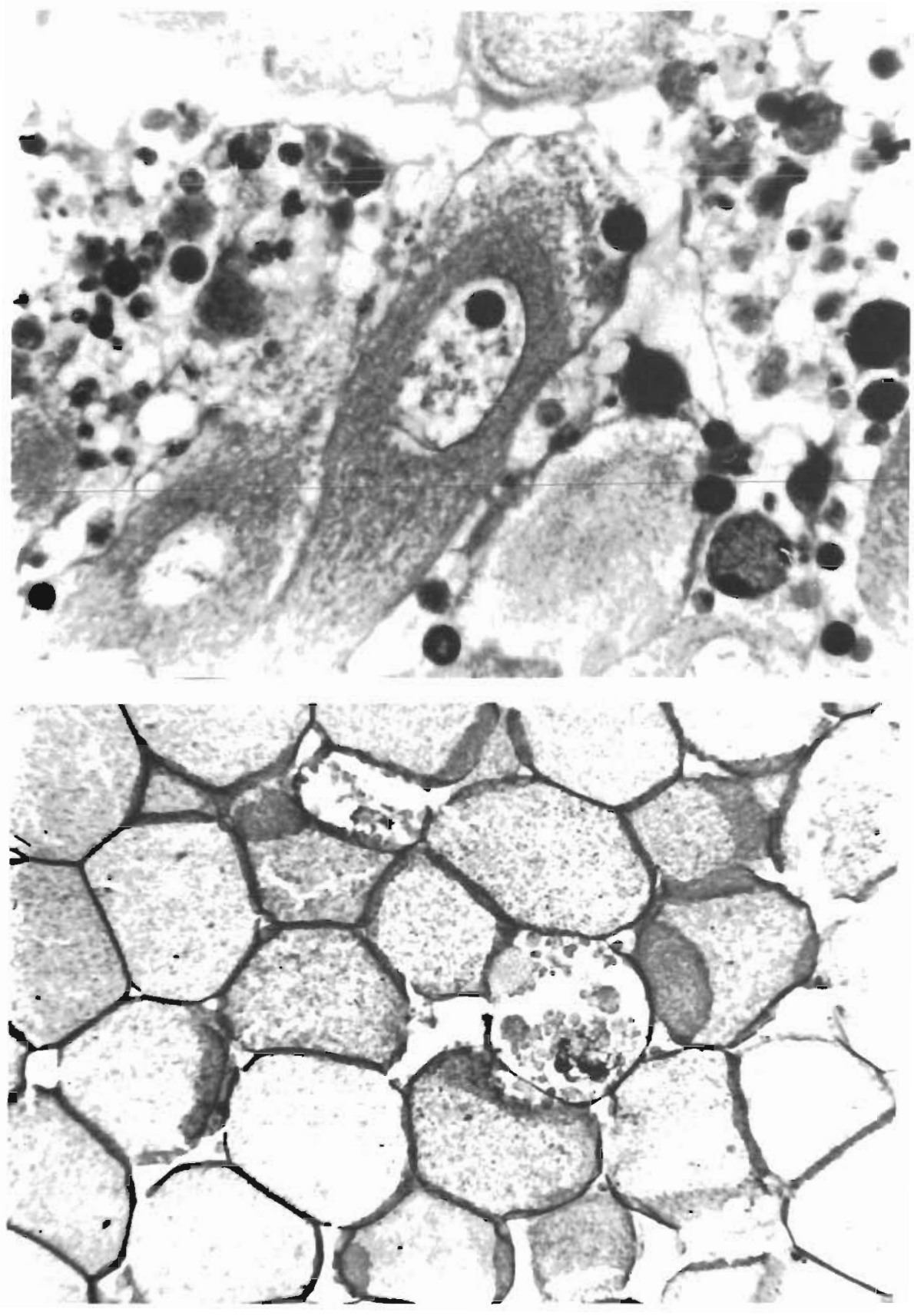

Fig. 4. Strongylocentrotus intermedius. Gonad under cadmium stress. Large ovocyte being resorbed. Cell envelope destroyed, globules of accessory cells intruding an ovocyte. Stain: as in Fig. 1. Magnification $900 \mathrm{X}$
Fig. 5. Strongylocentrotus intermedius. Gonad under cadmium stress. Resorbing egg cells distinctly seen in the center. Stain: as in Fig. 1. Magnification $600 \mathrm{X}$ 
for $1 \mathrm{mg} \mathrm{Cd} \mathrm{l}^{-1}$, this $\mathrm{Cd}$ concentration resulted in resorption of growing and ripe gametes.

$C d$ concentration of $0.1 \mathrm{mg} \mathrm{I}^{-1}$. The test urchins survived this $C d$ concentration for the $40 \mathrm{~d}$ experimental period. Behaviour was unaltered, although food intake

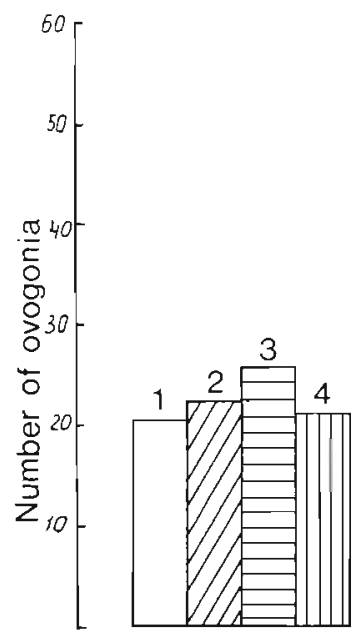

10 days

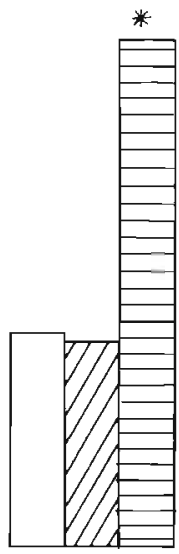

$20 d$

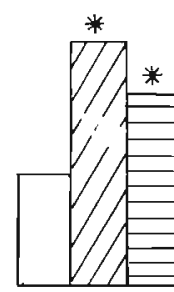

$30 \mathrm{~d}$
Fig. 6. Strongylocentrotus intermedius. Change in number of ovogonia in gonad. 1 , control; $2,0.1 \mathrm{mg} \mathrm{Cd} \mathrm{l}{ }^{-1} ; 3,0.5 \mathrm{mg}$

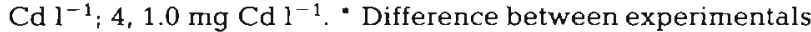
and controls significant $(P \leqslant 0.05)$

was lower. Nevertheless, embryogenesis resulted in anomalous plutei.

This Cd concentration did not induce any appreciable histological changes in the development of ovocytes. However, the number of ovogonia distinctly increased by the end of the experiment and was 1.5 times higher than in the controls.

\section{DISCUSSION}

Histological examination of Strongylocentrotus intermedius exposed to high $\mathrm{Cd}$ concentrations resulted in resorption of many growing ovocytes and ripe egg cells. Degenerative changes in the ovaries of test urchins occurred, compared with controls. The number of gigantic globules - heterophagosomes increased markedly in association with sex-cell resorption (Takashima, 1978; Varaksina, 1978).

Under natural conditions, an increase in the volume of accessory cells and growth of globular inclusions are observed in autumn and winter, when gonad resorption processes predominate in sea urchins. Formation of gigantic globules in the ovaries at active gametogenesis therefore should be evidence for degenerative processes in sex cells affected by toxic substance.

It appeared that $\mathrm{Cd}$ concentration of $0.5 \mathrm{mg} \mathrm{l}^{-1}$ induced both resorption of ovocytes and temporary increase in ovogonium number. Formation of an increased number of ovogonia might be an adaptive response to cadmium stress: this response uses the potential of gonads to form numerous sex cells rapidly to substitute for resorbed ones. Our observations on sea-urchin embryogenesis suggest that this may be a regulatory attempt of the organism to adjust for gamete loss.

A low percentage of fertilized egg cells in test urchins by the end of the first $10 \mathrm{~d}$ of $\mathrm{Cd}$ exposure suggests a low quality of sex products, which might be due to gamete resorption. However, at $\mathrm{Cd}$ concentration of $0.5 \mathrm{mg} \mathrm{l}^{-1}$, urchins were able to intensify generative processes in their gonads. In the $20 \mathrm{~d}$ exposure test, this led to an increase in the number of ovogonia and to a sharp increase in the number of fertilized egg cells (about $90 \%$ ). At $0.1 \mathrm{mg} \mathrm{Cd} \mathrm{l}^{-1}$, the number of egg cells with formed fertilization membranes exceeded $96 \%$ by the end of the twentieth day. This suggests that sex products were normal in quality. At least, these gametes would not be rejected by the 95-\%-fertilization embryological test (Buznikov and Podmarev, 1975).

In acute experiments with sea urchin zygotes at 0.5 and $0.1 \mathrm{mg} \mathrm{Cd} \mathrm{l}^{-1}$, the number of normal plutei were 67.9 and $83.7 \%$, respectively (Vlasova and Khristoforova, 1982). In this study with chronic exposure of adult urchins to $0.1 \mathrm{mg} \mathrm{Cd} \mathrm{Cl}^{-1}$ and above, and with maintenance of developing zygotes in clean water, embryogenesis after artificial insemination resulted in $100 \%$ anomaly. Thus, chronic cadmium exposure of mature individuals even to low $\mathrm{Cd}$ concentration is more harmful than short-term cadmium exposure of developing embryos.

Since no evident histological anomalies were found in the ovaries of Strongylocentrotus intermedius chronically exposed to $0.1 \mathrm{mg} \mathrm{Cd} \mathrm{m}^{-1}$, we suggest that the anomalous offspring resulted from some subcellular (e.g. metabolic) alterations in sex cells. A similar effect was observed by Vashchenko (1980), studying the influence of water-soluble hydrocarbons of light Diesel fuel on the development of sex cells in $S$. nudus. The latter author found that the sex cells of test urchins exposed chronically to sublethal concentrations of hydrocarbons produced anomalous offspring in spite of the absence of morphological changes in their gonads.

It was not an objective of our study to investigate how chronic exposure to toxic substances may affect the generative phase of ovocyte growth - the stage when major chromosomal transformations occur in the nucleus - or the vegetative phase associated with cytoplasmic growth and with accumulation of reserve material for nutrition of embryos. Nevertheless, from our results we conclude that (1) chronic exposure of 
mature Strongylocentrotus intermedius to cadmium in concentrations at and above $0.1 \mathrm{mg} \mathrm{l}^{-1}$ leads to formation of anomalous sex cells and to production of inviable offspring, and (2) absence of obvious histological alterations in ovarian acini is not sufficient evidence that gametogenesis following chronic exposure of mature adults to cadmium will be successful.

Acknowledgements. The authors thank Professor A. V. Zhirmunsky for critical reading of the manuscript and Mrs. Irina Barsegova for preparation of the text.

\section{LITERATURE CITED}

Buznikov, G. A., Podmarev, V. K. (1975). The sea urchins, Strongylocentrotus dröbachiensis, $S$. nudus, and $S$. intermedius. In: Detlaf, T. A. (ed.) Objects of developmental biology (Russ.). Nauka, Moscow, p. 188-216

Fuji, A. (1960a). Studies on the biology of the sea urchin. I. Superficial and histological changes in gametogenic process of two sea urchins, Strongylocentrotus nudus and $S$. intermedius. Bull. Fac. Fish. Hokkaido Univ. 11: 1-14

Fuji, A. (1960b). Studies on the biology of the sea urchin. III. Reproductive cycle of two sea urchins, Strongylocentrotus nudus, S. intermedius, in southern Hokkaido. Bull. Fac. Fish. Hokkaido Univ. 11: 49-57

Gnezdilova, S. M. (1971). Marine and cytochemical characteristics of ovogenesis and sex cycles in the sea urchins, Strongylocentrotus nudus and $S$. intermedius (Russ.). Cand. Biol. Sci. thesis, Institute of Marine Biology, FESC, USSR Ac. Sci., Vladivostok

Gnezdilova, S. M., Varaksina, G. S., Novikova, G. P. (1979). Comparative characteristics of reproductive cycles in sea urchins and starfishes. In: Zhirmunsky, A. V. (ed.) XIV. Pacific Science Congress, Committee for Marine Sciences, Section F. Ila, Moscow, p. 117-118

Kobayashi, J. (1971). Relation between 'itai-itai' disease and the population of river water by cadmium from a mine. Adv. Wat. Pollut. Res. 1: 1-32

Nozdryukhina, L. P. (1977). Biological role of trace elements in man and animal (Russ.). Nauka, Moscow

Pařizek, H. (1977). Factors determining response of organisms to introduction of some elements. In: Trace elements in medicine. Zdorovya, Kiev 7: 106-109

Patin, S. A., Morosov, N. P., Romanteeva, A. S., Melnikova, R. M., Borisenko, G. S. (1980). Trace elements in the ecosystem of the Sea of Japan (Russ.). Geokhimiya (Geochemistry) 3: 423-429

Takashima, Y., Tominaga, Kume, T. (1978). Formation and behaviour of the nurse cell giant granules in the sea urchin ovary. 9th Int. Congr. Electron. Microsc., Toronto, Vol. 2: 554-555

Varaksina, G. S. (1978). Histophysiology of accessory cells of the gonad of the sea urchins, Strongylocentrotus nudus and S. intermedius (Russ.). Cand. Biol. Sci. thesis, Institute of Cytology, USSR Ac. Sci., Leningrad

Vashchenko, M. A. (1980). Influence of watersoluble hydrocarbons of light diesel fuel upon the development of sex cells and the quality of the offspring in the sea urchin, Strongylocentrotus nudus (Russ.). Mar. Biol., Vladivostok 4: $68-73$

Vlasova, G. A., Khristoforova, N. K. (1982). Effect of cadmium upon early ontogenesis of the sea urchin, Strongylocentrotus intermedius (Russ.). Mar. Biol., Vladivostok 4: $31-36$

Yakovlev, S. M. (1980). The sea urchin, Strongylocentrotus intermedius. In: Milejkovsky, S. A. (ed.) Reproduction of echinoderms and bivalve molluscs (Russ.). Nauka, Moscow, p. 42-51

This paper was presented by Professor A. V. Zhirmunsky; it was accepted for printing on November 25, 1983 